\title{
Pengaruh variasi berat polimer terhadap sifat fisik Patch NaF
}

\author{
Diyah Fatmasari, Endah Aryati Eko Ningtyas, Ani Subekti \\ Poltekkes Kemenkes Semarang, Jawa Tengah, Indonesia \\ JI Tirto Agung Pedalangan, Semarang, Jawa Tengah, Indonesia; e-mail: fatmasaridiyah@gmail.com
}

Submisi: 19 Januari 2017; Penerimaan: 5 Juni 2017; Publikasi online: 29 Desember 2017

\begin{abstract}
ABSTRAK
Fluorida sudah terbukti sebagai bahan untuk memperkuat permukaan gigi. Berbagai sediaan fluoride sudah banyak ditemukan. Sediaan fluoride yang terbaru adalah dalam bentuk plester yang melepaskan ion fluorida lewat kulit. Sediaan plester sodium fluorida (NaF) sudah ditemukan tetapi belum ada lapran mengenai sifat fisik plester berdasarkan variasi polimer yang digunakan. Tujuan penelitian adalah untuk mendapatkan plester dengan variasi berat polimer yang menghasilkan sifat fisik yang baik. Desain penelitian adalah quasy experimental dengan post test groupresearch design sebagai rancangan penelitian. Variabel pengaruh adalah variasi polimer dan lama penyimpanan (1 dan 7 hari), variabel terpengaruh adalah ketebalan, daya tahan terhadap lipatan, berat, kandungan obat, persentase moisture uptake dan persentase loss on drying. Pembuatan plester NaF menggunakan solvent casting method PVA; PVP dipanaskan dalam water bath sampai polimer larut; $\mathrm{NaF} 100 \mathrm{mg}$ diaduk dalam $2 \mathrm{ml}$ aquabides; 0,1 ml asam oleat; 0,1 $\mathrm{ml}$ IPA dicampur menjadi satu dalam tabung kacadan dilarutkan dalam $3,8 \mathrm{ml}$ aquabides. Dibuat 3 jenis plester $\mathrm{NaF}$ dengan konsentrasi polimer bervariasi. Semua bahan kemudian dicampur menjadi satu dalam tabung kaca dan diaduk sampai larut, dituang dalam cawan petri dan didiamkan selama \pm 3 hari. Jika sudah kering maka matriks diambil dengan pisau khusus dan disimpan dalam alumunium foil sampai digunakan. Hasil penelitian menunjukkan adanya perbedaan sifat fisik pada ke tiga jenis plester NaF. Plester dengan perbandingan PVP : PVA = $1: 2$ menghasilkan sifat fisik paling baik. Penyimpanan dalam alumunium foil tidak menyebabkan terjadinya perbedaan sifat fisik plester $\mathrm{NaF}$. Plester $\mathrm{NaF}$ dengan variasi polimer yang baik dapat dikembangkan untuk penelitian selanjutnya. Perlu dikembangkan plester NaF dengan variasi polimer terbaik.
\end{abstract}

Kata kunci: plester NaF; polimer; sifat fisik

\begin{abstract}
Influence of weight polymer variation towards sodium fluoride patch physical properties. Fluoride has been proven as a material for strengthen teeth. Many fluoride modalities are available nowadays, and the recent is sodium fluoride (NaF) patch which delivers fluoride via transdermal. No report was found about the physical properties of $\mathrm{NaF}$ patch based on polymer variation used. Research purpose was to find $\mathrm{NaF}$ patch with polymer variation which has good physical properties. Research design was quasy experimental with post test group research as research approach. Dependent variables included polymer variation and stored time; independent variable included patch thickness; resistance of folding; weight; drug content; percentage of moisture uptake and percentage loss on drying. $\mathrm{NaF}$ Patch manufacturing used solvent casting method the polymer PVA and PVP mixed in $2 \mathrm{ml}$ aquabidest inwater bath until polymer dissolved; $100 \mathrm{mg}$ of $\mathrm{NaF}$ mixed in $2 \mathrm{ml}$ aquabi 0,1 ml oleic acid; 0,1 ml IPA mixed in glass tube and dissolved in 3,8 ml aquabidest. Three kinds of $\mathrm{NaF}$ patch with polymer variation were made. All materials were mixed in glass tube and stirred until dissolved, then pour into petry disc and allowed for 3 days until it dry. Research result showed a difference of physical properties among three NaF patch. Patch with variation PVP:PVA $=1: 2$ resulted in the best physical properties. Storing patch in aluminum foil did not cause any differences of physical properties. NaF patch with good polymer variation can be developed for further research.
\end{abstract}

Keywords: NaF patch; polymer; physical properties

\section{PENDAHULUAN}

Fluorida terbukti efektif dalam upaya peningkatan daya tahan permukaan gigi terhadap karies. Sediaan fluorida yang tersedia baik topikal dan sistemik dianjurkan diberikan dalam dosis kecil, perlahan-lahan dan jangka panjang. ${ }^{1}$ Salah satu sediaan terbaru yang bisa memenuhi kriteria tersebut adalah dalam bentuk transdermal drug delivery. ${ }^{2}$ Uji coba pembuatan patch berisi Natrium Fluorida ( $\mathrm{NaF}$ ) dikemas secara manual dengan menggunakan kassa serta kertas minyak sebagai bahan pembawa obat telah dilakukan. ${ }^{3}$ Setelah penyimpanan ditemukan bahwa terjadi pengurangan jumlah obat dalam kemasan, sehingga harus dikembangkan plester dengan metode lain. 
Penelitian sebelumnya menunjukkan bahwa plester dengan solvent casting method menunjukkan adanya fluorida yang dapat menembus kulit tikus setelah uji transpor selama 4 jam. Metode solvent casting dilakukan dengan cara mencampur obat, polymer, bahan enhancer dan bahan pelarut kemudian dilarutkan dalam suhu kamar. ${ }^{4}$ Penelitian menggunakan uji transport untuk mengetahui apakah fluorida dapat menembus kulit dengan menggunakan tabung Franz Like Diffusion Cell dan kulit tikus digunakan sebagai membran, tabung donor adalah larutan $\mathrm{NaF}$ dan tabung reseptor

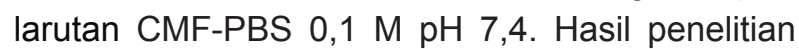
sebelumnya menunjukkan adanya fluorida yang dapat menembus kuliy setelah uji transpor selama 4 jam. Polimer yang digunakan dalam pembuatan patch ini adalah Poly vinyl alcohol (PVA) dan Poly vynil pyrilidone (PVP). Kedua polimer ini merupakan bahan pengisi utama dari pembuatan patch. Hasil penelitian sebelumnya menunjukkan perbandingan konsentrasi dari polimer dalam pembuatan plester $\mathrm{NaF}$ adalah PVP : PVA $=1: 2$ dengan hasil baik. ${ }^{5}$ Hasil dari formulasi tersebut belum dilakukan pengamatan terhadap sifat fisik (ketebalan, daya tahan terhadap lipatan, berat, kandungan obat, persentase moisture uptake dan persentase loss on drying) patch sehingga perlu ditambah dengan variasi perbandingan polimer yang digunakan. Tujuan penelitian ini adalah mengukur sifat fisik $\mathrm{NaF}$ patch dengan berbagai variasi polimer dalam pembuatannya.

\section{METODE PENELITIAN}

Jenis penelitian adalah kuasi experimental dengan post test only group design sebagai rancangan penelitian. Surat layak etik didapatkan dari Komisi Etik Penelitian Kesehatan Poltekkes Semarang. Pembuatan patch di laboratorium kimia Jurusan Analis Kesehatan Poltekkes Semarang dengan hasil 3 variasi patch dilanjutkan dengan evaluasi karakteristik fisik patch transdermal. Variasi konsentrasi PVA dan PVP yaitu 1:1; $1: 2$ dan $2: 1$, didapatkan dengan mengukur berat PVA dan PVP sebagai polimer sebesar $500 \mathrm{mg} .{ }^{6}$ Jika perbandingan 1;1 maka berat PVA dan PVP masing-masing adalah $250 \mathrm{mg}$, jika perbandingan
1 : 2 maka PVA sebanyak $333 \mathrm{mg}$ dan PVP sebanyak $167 \mathrm{mg}$ demikian sebaliknya. Jumlah sampel per kelompok adalah 3 dan replikasi pengukuran dilakukan sebanyak 3 kali.

Lama penyimpanan adalah waktu patch disimpan dalam desicator selama 1 dan 7 hari. Variabel terikat adalah variasi ketebalan plester; daya tahan terhadap lipatan; variasi berat plester; variasi konsentrasi $\mathrm{NaF}$; persentase moisture uptake adalah kelembaban yang dapat masuk ke dalam patch selama penyimpanan dalam desicator dan persentase loss on drying adalah kelembaban yang hilang dari patch dikarenakan terpapar dengan udara terbuka.

Plester $\mathrm{NaF}$ menggunakan metode solvent casting dengan cara melarutkan 333 mg PVA dalam $2 \mathrm{ml}$ aquabides (diaduk dengan pengaduk); melarutkan $167 \mathrm{mg}$ PVP dalam $2 \mathrm{ml}$ aquabides dipanaskan dalam water bath sampai polimer larut; melarutkan $\mathrm{NaF}$ seberat $100 \mathrm{mg}$ dalam 2 $\mathrm{ml}$ aquabides (diaduk dengan pengaduk); $0,1 \mathrm{ml}$ asam oleat; $0,1 \mathrm{ml}$ IPA dicampur menjadi satu dalam tabung kacadan dilarutkan dalam $3,8 \mathrm{ml}$ aquabides. Dibuat 3 jenis plester $\mathrm{NaF}$ dengan konsentrasi polimer bervariasi. Berat polimer untuk jenis plester yang kedua adalah PVA $(250 \mathrm{mg})$ dan PVP $(250 \mathrm{mg})$. Berat PVA adalah $167 \mathrm{mg}$ dan berat PVP adalah $333 \mathrm{mg}$ untuk Plester $\mathrm{NaF}$ yang ketiga. ${ }^{6}$ Semua bahan kemudian dicampur menjadi satu dalam tabung kaca dan diaduk sampai larut. Tahap selanjutnya campuran larutan dituang dalam cawan petri dan didiamkan selama \pm 3 hari. Jika sudah kering maka matriks diambil dengan pisau khusus dan disimpan dalam aluminium foil sampai digunakan. Pembuatan patch dilakukan di laboratorium farmasi UGM.

Plester NaF dengan 3 buah variasi polimer dengan masing-masing 3 buah sebagai sampel diukur ketebalannya. Ketebalan diukur dengan menggunakan sliding calipers pada 3 titik pada masing-masing plester. Hasil 3 kali pengukuran kemudian di rata-rata.

Setiap plester $\mathrm{NaF}$ dilipat berkali-kali sampai robek. Daya tahan terhadap lipatan diukur dengan menghitung pada lipatan ke berapa plester robek. 
Variasi berat plester setiap plester ditimbang dengan menggunakan neraca digital. Penimbangan dilakukan sampai didapatkan hasil pengukuran yang stabil. Berat yang didapat dari penimbangan 3 buah sampel kemudian di rata-rata.

Pengukuran konsentrasi NaF dalam tiap plester dilakukan dengan menggunakan potensiometer spesifik ion $\mathrm{F}$ yang ada di BATAN Jogjakarta. Plester dilarutkan dalam aquabidest kemudian dianalisa di laboratorium kimia BATAN untuk pengukuran kandungan $\mathrm{NaF}$ dalam masingmasing plester.

Persentase moisture uptake diukur dengan cara sampel plester $\mathrm{NaF}$ disimpan dalam dissicator yang diberi bahan pengawet silica gel selama 24 jam. Sebelum penyimpanan diukur berat plester, setalah 24 jam dilakukan penimbangan ulang.

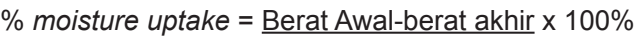
Berat akhir ....... persamaan 1)

Persentase loss on drying diukur dengan cara semua plester $\mathrm{NaF}$ disimpan dalam ruang terbuka (terpapar udara). Sebelum perlakuan, semua plester $\mathrm{NaF}$ ditimbang sebagai berat awal. Setelah terpapar udara selama 3 hari, kemudian dilakukan penimbangan lagi (berat akhir). Dilakukan penghitungan porsentase loss on drying dengan rumus:

$\%$ loss on drying $=$ Berat Awal-berat akhir $\times 100 \%$ Berat akhir ….... persamaan 2)

Data yang diperoleh dari ke 6 test karakteristik fisik selanjutnya dianalisis dengan uji Analisis Variansi satu jalur (One Way ANOVA) dengan syarat data berditribusi normal dan homogeny, dengan signifikan pada $p<0,05$. Uji post hoct dilakukan untuk melihat kelompok mana yang memberikan pengaruh hasil terbaik.

\section{HASIL PENELITIAN}

Pembuatan plester $\mathrm{NaF}$ dengan metode solvent casting method didapatkan hasil sbb:

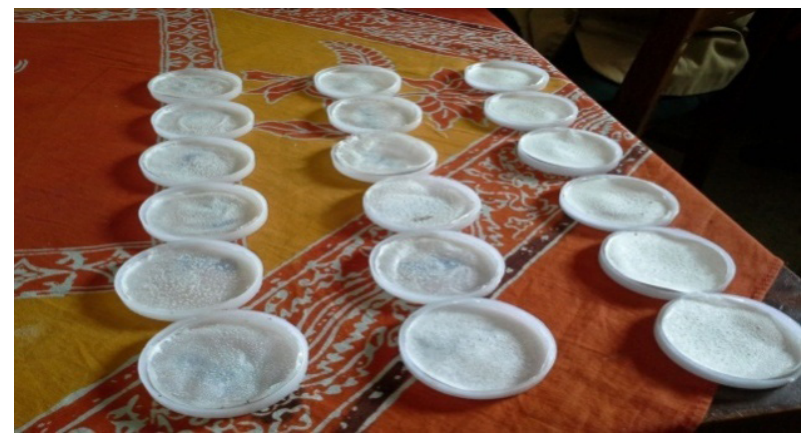

Gambar 1. Plester NaF dengan berbagai variasi perbandingan polimer sebelum dikeluarkan dari petri

Setelah dihasilkan sediaan plester $\mathrm{NaF}$ dengan hasil homogen, selanjutnya dilakukan pengukuran sifat fisik plester $\mathrm{NaF}$ pada hari 1,7 . Tebal plester tidak mengalami penurunan setelah dilakukan penyimpanan selama 7 hari.

Karakteristik daya tahan plester terhadap lipatan menunjukkan ketahanan plester terhadap tekanan terhadap lipatan yang dilakukan berulang kali. Berdasarkan uji analitik diketahui tidak ada perbedaan daya tahan terhadap lipatan setelah penyimpanan. Berat plester setelah penyimpanan ternyata tidak mengalami penurunan secara signifikan setelah disimpan selama 7 hari. Konsentrasi obat $\mathrm{NaF}$ dalam plester tidak mengalami penurunan/perubahan secara signifikan setelah disimpan selama 7 hari. Berdasarkan uji statistik diketahui kelembaban yang terserap dalam plester tidak mengalami perubahan setelah penyimpanan selama 7 hari. Persentase kehilangan kelembaban pada plester tidak mengalami perbedaan setelah penyimpanan selama 7 hari.

\section{PEMBAHASAN}

Plester yang digunakan dalam pengobatan diaplikasikan dalam permukaan tubuh/kulit, sehingga membutuhkan sifat/karakteristik yang baik sehingga dapat bertahan selama beberapa waktu. Plester harus bersifat lentur, tidak mudah pecah, mempunyai berat ringan dan tipis. ${ }^{2}$ 
Majalah Kedokteran Gigi Indonesia. Desember 2017; 3(3): 153 - 159

ISSN 2460-0164 (print)

ISSN 2442-2576 (online)

Tabel 1. Rerata, standar deviasi (SD) karakteristik fisik plester $\mathrm{NaF}$ setelah 1 hari penyimpanan $(n=3)$

\begin{tabular}{ccccccc}
\hline $\begin{array}{c}\text { Variasi poli- } \\
\text { mer } \\
(\mathrm{PVP}: \mathrm{PVA})\end{array}$ & $\begin{array}{c}\text { Ketebalan } \\
\text { Plester } \\
(\mathrm{mm}) \pm \mathrm{SB}\end{array}$ & $\begin{array}{c}\text { Daya tahan } \\
\text { terhadap } \\
\text { lipatan } \pm \mathrm{SB}\end{array}$ & $\begin{array}{c}\text { Berat }(\mathrm{mg}) \\
\text { Plester } \pm \mathrm{SB}\end{array}$ & $\begin{array}{c}\text { Konsentrasi NaF } \\
(\mathrm{ppm}) \pm \mathrm{SB}\end{array}$ & \% moisture uptake $\pm \mathrm{SB}$ & $\begin{array}{c}\% \text { loss on } \\
\text { drying } \pm \mathrm{SB}\end{array}$ \\
\hline $1: 1$ & $0,27 \pm 0,26$ & $9 \pm 1$ & $0,21 \pm 0,25$ & $0,6 \pm 0,5$ & $17,3 \pm 0,76$ & $8,6 \pm 1,2$ \\
$1: 2$ & $0,20 \pm 0,02$ & $11,6 \pm 1,5$ & $0,18 \pm 0,02$ & $0,7 \pm 0,05$ & $16,6 \pm 0,7$ & $6,5 \pm 0,5$ \\
$2: 1$ & $0,3 \pm 0,05$ & $8,6 \pm 1,15$ & $0,27 \pm 0,03$ & $0,6 \pm 0,45$ & $18 \pm 0,5$ & $10,8 \pm 1,04$ \\
\hline Kemaknaan & $0,01^{*}$ & $0,04^{*}$ & $0,04^{*}$ & 0,07 & $0,04^{*}$ & $0,005^{*}$ \\
\hline
\end{tabular}

Tabel 2. Rerata, standar deviasi (SD) karakteristik fisik plester NaF setelah 7 hari penyimpanan $(n=3)$

\begin{tabular}{ccccccc}
\hline $\begin{array}{c}\text { Variasi poli- } \\
\text { mer } \\
(\mathrm{PVP}: \mathrm{PVA})\end{array}$ & $\begin{array}{c}\text { Ketebalan } \\
\begin{array}{c}\text { Plester } \\
(\mathrm{mm}) \pm \mathrm{SB}\end{array}\end{array}$ & $\begin{array}{c}\text { Daya tahan } \\
\text { terhadap } \\
\text { lipatan } \pm \mathrm{SB}\end{array}$ & $\begin{array}{c}\text { Berat } \\
\text { Plester } \pm \mathrm{SB}\end{array}$ & $\begin{array}{c}\text { Konsentrasi } \\
\text { NaF } \pm \mathrm{SB}\end{array}$ & $\%$ moisture uptake $\pm \mathrm{SB}$ & $\begin{array}{c}\text { \% loss on } \\
\text { drying } \pm \mathrm{SB}\end{array}$ \\
\hline $1: 1$ & $0,27 \pm 0,03$ & $7,3 \pm 1,1$ & $0,18 \pm 0,03$ & $0,6 \pm 0,1$ & $15,8 \pm 0,76$ & $8 \pm 1$ \\
$1: 2$ & $0,20 \pm 0,02$ & $10 \pm 1$ & $0,15 \pm 0,03$ & $0,7 \pm 0,05$ & $15,5 \pm 1,8$ & $6 \pm 1$ \\
$2: 1$ & $0,30 \pm 0,05$ & $6,3 \pm 1,5$ & $0,16 \pm 0,1$ & $0,8 \pm 0,06$ & $17,3 \pm 0,5$ & $10,3 \pm 1,6$ \\
\hline Kemaknaan & $0,04^{*}$ & $0,02^{*}$ & 0,08 & 0,08 & 0,2 & $0,003^{*}$ \\
\hline
\end{tabular}

Tabel 3. Rerata, standar deviasi Perbedaan ketebalan plester pada hari 1 dan ke 7 setelah penyimpanan

\begin{tabular}{|c|c|c|c|}
\hline \multirow{2}{*}{$\begin{array}{l}\text { Variasi polimer } \\
\text { (PVP : PVA) }\end{array}$} & \multicolumn{2}{|c|}{ Ketebalan Plester $(\mathrm{mm}) \pm \mathrm{SB}$} & \multirow{2}{*}{$\begin{array}{l}\text { Kemaknaaan Independent } \\
\text { t test }\end{array}$} \\
\hline & 1 hari & 7 hari & \\
\hline $1: 1$ & $0,27 \pm 0,26$ & $0,27 \pm 0,03$ & 0,19 \\
\hline $1: 2$ & $0,20 \pm 0,02$ & $0,20 \pm 0,02$ & 0,09 \\
\hline $2: 1$ & $0,3 \pm 0,05$ & $0,30 \pm 0,05$ & 0,27 \\
\hline
\end{tabular}

Tabel 4. Perbedaan daya tahan terhadap lipatan plester pada hari 1 dan ke 7 setelah penyimpanan

\begin{tabular}{cccc}
\hline \multirow{2}{*}{$\begin{array}{c}\text { Variasi polimer } \\
\text { (PVP : PVA) }\end{array}$} & \multicolumn{2}{c}{$\begin{array}{c}\text { Daya tahan terhadap lipatan } \\
\text { Plester } \pm \text { SB }\end{array}$} & \multirow{2}{*}{$\begin{array}{l}\text { Kemaknaaan } \\
\text { test }\end{array}$} \\
\cline { 2 - 3 } & 1 hari & 7 hari & \\
\hline $1: 1$ & $9 \pm 1$ & $7,3 \pm 1,1$ & 0,13 \\
$1: 2$ & $11,6 \pm 1,5$ & $10 \pm 1$ & 0,19 \\
$2: 1$ & $8,6 \pm 1,15$ & $6,3 \pm 1,5$ & 0,10 \\
\hline
\end{tabular}

Tabel 5. Perbedaan berat plester pada hari 1 dan ke 7 setelah penyimpanan

\begin{tabular}{cccl}
\hline $\begin{array}{c}\text { Variasi polimer } \\
\text { (PVP : PVA) }\end{array}$ & \multicolumn{2}{c}{$\begin{array}{c}\text { Berat }(\mathrm{mg}) \\
\text { Plester } \pm \text { SB }\end{array}$} & \multirow{2}{*}{$\begin{array}{l}\text { Kemaknaaan Independent } \\
\text { t test }\end{array}$} \\
\cline { 2 - 3 } & 1 hari & 7 hari & 0,15 \\
$1: 1$ & $0,21 \pm 0,25$ & $0,18 \pm 0,03$ & 0,09 \\
$2: 1$ & $0,18 \pm 0,02$ & $0,15 \pm 0,03$ & 0,4 \\
\hline
\end{tabular}

Tabel 6. Perbedaan konsentrasi obat dalam plester pada hari 1 dan ke 7 setelah penyimpanan

\begin{tabular}{|c|c|c|c|}
\hline \multirow[t]{2}{*}{ Variasi polimer (PVP:PVA) } & \multicolumn{2}{|c|}{$\begin{array}{c}\text { Konsentrasi } \mathrm{NaF} \\
\text { Plester } \pm \mathrm{SB}\end{array}$} & \multirow[t]{2}{*}{$\begin{array}{l}\text { Kemaknaaan Independent } t \\
\text { test }\end{array}$} \\
\hline & 1 hari & 7 hari & \\
\hline $1: 1$ & $0,6 \pm 0,5$ & $0,6 \pm 0,1$ & 1 \\
\hline $1: 2$ & $0,7 \pm 0,05$ & $0,7 \pm 0,05$ & 0,3 \\
\hline $2: 1$ & $0,6 \pm 0,45$ & $0,8 \pm 0,06$ & 0,5 \\
\hline
\end{tabular}


Tabel 7. Perbedaan \% moisture uptake dalam plester pada hari 1 dan ke 7 setelah penyimpanan

\begin{tabular}{cccc}
\hline $\begin{array}{c}\text { Variasi polimer } \\
\text { (PVP : PVA) }\end{array}$ & \multicolumn{2}{c}{$\begin{array}{c}\text { \% moisture uptake } \\
\text { Plester } \pm \text { SB }\end{array}$} & \begin{tabular}{c} 
Kemaknaaan \\
test \\
\cline { 2 - 4 }
\end{tabular} \\
\cline { 2 - 4 } $1: 1$ & 1 hari & $15,8 \pm 0,76$ & 0,07 \\
$1: 2$ & $17,3 \pm 0,76$ & $15,5 \pm 1,8$ & 0,4 \\
$2: 1$ & $16,6 \pm 0,7$ & $17,3 \pm 0,5$ & 0,06 \\
\hline
\end{tabular}

Tabel 8. Perbedaan \% loss on drying dalam plester pada hari 1 dan ke 7 setelah penyimpanan

\begin{tabular}{cccc}
\hline $\begin{array}{c}\text { Variasi polimer } \\
\text { (PVP : PVA) }\end{array}$ & \multicolumn{2}{c}{$\begin{array}{c}\text { \% loss on drying } \\
\text { Plester } \pm \text { SB }\end{array}$} & \begin{tabular}{c} 
Kemaknaaan \\
test \\
\cline { 2 - 4 }
\end{tabular} \\
\hline $1: 1$ & 1 hari & $8 \pm 1$ & 0,5 \\
$1: 2$ & $8,6 \pm 1,2$ & $6 \pm 1$ & 0,5 \\
$2: 1$ & $6,5 \pm 0,5$ & $10,3 \pm 1,6$ & 0,5 \\
\hline
\end{tabular}

Setelah dilakukan uji pembuatan plester dengan variasi rasio polimer pada penelitian ini ditemukan adanya perbedaan karakteristik sifat fisik plester. Polimer yang digunakan ada 2 macam yaitu PVP dan PVA. Polimer pada pembuatan plester ibarat tulang belakang dalam suatu sistem transdermal. Pembuatan NaF patch dengan dua polimer yaitu PVA dan PVP, biasanya satu polimer berperan mencegah obat segera keluar dari sediaan dan polimer lainnya berperan sebagai bahan perekat (adhesive). ${ }^{7}$ PVA bersifat larut dalam air dan akan mengalami disolusi pada keadaan lingkungan yang lembab dengan cara dicampur dengan air. Polimer ini mempunyai bobot molekul 20.000 dalton. PVP mempunyai sifat larut dalam air serta pelarut organik seperti alkohol dengan bobot molekul antara 10.000-50.000. Kedua polimer ini bersifat cross-linked yaitu dapat berikatan satu sama lain. ${ }^{8}$

PVA dan PVP berperan dalam hal mengkontrol lepasnya obat $(\mathrm{NaF})$ serta melindunginya dari sediaan plester $\mathrm{NaF}$ dalam bentuk molekul mempunyai sifat mudah larut dalam air dapat berikatan dengan kedua polimer setelah tercampur dalam sediaan. Mekanisme perlindungan polimer terhadap obat dengan cara memperlambat $\mathrm{NaF}$ larut, serta menghambat agar tidak segera keluar menembus matrix. Mekanisme pelepasan obat dari plester adalah dengan cara PVA dan PVP akan bereaksi membentuk pori-pori kecil yang menjadi jalan bagi obat untuk secara perlahan-lahan akan melepaskan diri dari ikatan polimer. ${ }^{9}$
Berdasarkan uji karakteristik sifat fisik plester $\mathrm{NaF}$ setelah 1 hari penyimpanan, plester yang menggunakan rasio PVP : PVA sebanyak $1: 2$ menghasilkan sediaan dengan karakteristik lebih baik yaitu paling tipis, paling ringan, kandungan $\mathrm{NaF}$ tinggi, ketahanan terhadap daya lipat paling tinggi, kemampuan menyerap kelembaban paling besar dan persentase menjadi kering paling kecil. PVP dan PVA mempunyai sifat sama yaitu larut dalam air, tetapi PVP mempunyai kekurangan yaitu jika diberikan secara berlebihan akan menimbulkan campuran menjadi tidak homogen. ${ }^{10}$ Rasio PVA lebih banyak akan meningkatkan kekuatan campuran dikarenakan adanya ikatan polar berasal dari polimer yang bersifat hidrofilik sehingga akan memperkuat ikatan diantara polimer dan bahan lain. ${ }^{11}$

Setelah penyimpanan selama 7 hari ditemukan bahwa ke enam sifat fisik pada tiga variasi polimer tidak mengalami perubahan secara berarti. Tebal plester yang rata-rata dalam kategori ringan, tidak mengalami penurunan ketebalan. Dalam penelitian ini, variasi polimer menghasilkan plester dengan tebal yang homogen. Hal ini dikarenakan berat obat yang digunakan adalah sama, berat polimer juga sama hanya rasionya saja yang berbeda.

Kekuatan plester terhadap daya lipat juga tidak mengalami perubahan. Kekuatan plester ditentukan oleh ikatan antar bahan yang digunakan. Ketiga jenis plester menggunakan komposisi yang sama antara polimer, obat, pelarut dan enhancer, sehingga daya tahan terhadap lipatan homogen. Setelah 
penyimpanan, tidak menyebabkan perubahan kekuatan dikarenakan dalam wadah tertutup kekuatan ikatan antar molekul tidak mengalami perubahan. ${ }^{12}$

Berat plester yang ditentukan oleh campuran dari bahan yang digunakan juga tidak mengalami perubahan yang berarti. Berat plester setelah disimpan tidak berubah karena dalam wadah tertutup tidak akan menyebabkan terjadi penguapan dari semua bahan yang digunakan. Kandungan obat $\mathrm{NaF}$ dalam plester juga tidak berkurang setelah disimpan selama 7 hari. Hal ini disebabkan karena adanya ikatan yang kuat antara NaF dengan polimer sehingga tidak akan merubah komposisi kandungan $\mathrm{NaF}^{13}$

Kemampuan plester untuk menyerap kelembaban dari udara tidak berbeda sebelum dan setelah penyimpanan selama 7 hari (Tabel 7 ). Hal ini dikarenakan penyimpanan dalam desicator yang terbuat dari bahan logam tertutup rapat, tidak ada udara untuk masuk sehingga tidak memungkinkan adanya peningkatan moisture uptake. Berdasarkan hasil penelitian ini, rasio polimer yang paling baik yang menghasilkan plester dengan sifat fisik baik adalah PVP : PVA sebanyak 1 : 2.

\section{KESIMPULAN}

Plester NaF dengan sifat fisik terbaik adalah dengan variasi polimer PVP : PVA sebanyak 1 : 2, lama penyimpanan selama 1 dan 7 hari penyimpanan tidak berpengaruh terhadap sifat fisik (ketebalan, daya tahan terhadap lipatan, berat, kandungan obat, persentase moisture uptake dan loss on drying) plester NaF.

\section{UCAPAN TERIMA KASIH}

Terima kasih kepada Direktur Politeknik Kesehatan Semarang atas hibah penelitian Risbin Poltekkes Semarang yang dipercayakan.

\section{DAFTAR PUSTAKA}

1. Cury JA, Tenuta LMA, Ribeiro CCC, Paes Leme AF. The importance of fluoride dentifrice to the current dental caries prevalence in Brazil. Braz Dent J. 2004; 15: 167 - 174.
2. Aggarwal G. Development, fabrication and evaluation of transdermal drug delivery system: a review. Latest Reviews. 2009; 7(5).

3. Fatmasari D. Trial of simple Natrium Fluoride patch on fluoride stability based on storage time and type of patch packaging. Proceeding book FDI-IDA joint Meeting; 2011. 156 - 160.

4. Fatmasari D, Dwiprahasto I, Nugroho AK, Widjijono. Can fluoride penetrate to the skin? (Pre eliminary study of fluoride transdermal drug delivery system). dentika Dental Journal. 2012; 17(1): $14-18$.

5. Fatmasari D, Dwiprahasto I, Nugroho AK, Widjijono. Additional of chemical enhancer for increasing the penetration fluoride mouse skin. Proceeding book The 2nd International Joint Symposium on Oral and Dental Sciences. 2013; ISBN: 978-602-9461-16-9.

6. Prabhakara $\mathrm{P}$, Koland M, Vijaynarayana $\mathrm{K}$, Haris NM, Shankar G, Mohd GA, Narayana C, Satyanarayana. Preparation and evaluation of transdermal patches of papaverine hydrochloride. J. Res. Pharm. 2010; 3: $259-266$.

7. Kandavill S, Nair V, Panchagnula R. Polymers in transdermal drug delivery system. Pharmaceutical Technology. 2002; (Cited 2015) available at www.pharmtech.com.

8. Guy RH. Current status and future prospects in transdermal drug delivery. Pharmaceutical Research.1996; 12: 1765 - 1769.

9. Baviskar DT, Parik VB, Gupta HN, Maniyar AH, Jain DK. Design and evaluation of patches for transdermal delivery of losartan potassium. J Pharm Sci Technol. 2012; 66(2): 126 - 135.

10. Anonim. Polyvinylpyrrolidone 2014; (Cited 2017) available at http://pslc.ws/macrog/nvp. $\mathrm{htm}$

11. Mc Ginity JW, Felton LA. "Chapter 9: Chemistry and application properties of polymethacrylate systems" in: aqueous polymeric coatings for pharmaceutical dosage forms. Ed(s): McGinity, JW, Felton LA. 3 rd ed. New York: Informa Healthcare; 2008. 237 - 277. 
12. MutalikS, Udupa N. Glibenclamide transdermal patches: physicochemical, pharmacodynamic, and pharmacokinetic evaluations. J Pharm Sci. 2004; 93:1577 - 1594.
13. Patel VM, Prajapati BG, Patel MM. Effect of hydrophilic polymers on buccoadhesive eudragit patches of propranolol hydrochloride using factorial design. AAPS Pharm Sci Tech. 2007; 8(2). 